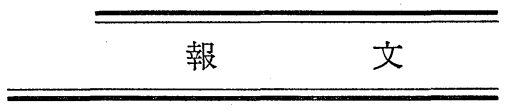

\title{
冷凍ニンジンの素揚げによるドリップ，オイル吸収，扔 よびカロチノイド残量に及ぼす凍結方法の影響について
}

\author{
EFFECT OF FREEZING METHODS ON DRIP, OIL ABSORPTION \\ AND CAROTENOID RETENTION IN FROZEN CARROTS \\ Hiraizumi, S. *, Higasiyama, K.*, and Luh, B. S. **
}

Summary

The effect of slow-freezing at $-20^{\circ} \mathrm{C}$ and liquid nitrogen freezing (LNF) at $-196^{\circ} \mathrm{C}$ on drip, oil absorption, and carotenoid retention in frozen carrots was investigated. The loss of fluid on thawing as evaluated by centrifugation was $4 \%$ in the slow-freezing samples, and $1 \%$ in the LNF samples. The difference in drip between the two treatments may be attributed to the change in cell wall structre having the alow-freezing process at $-20^{\circ} \mathrm{C}$. Slow freezing causes damage to the structure and texture of frozen carrots due to crushing and tearing of the tissues during ice formation. When the frozen carrot slices were thawed at room temperature for one hour and then reach $3 \%$. Oil fried in salad oil at 160 to $170^{\circ} \mathrm{C}$ for 30 to 60 seconds, the oil absorption by the carrot tissue may absorption by the carrot slices varied with degree of thawing, time of frying, and the methods of freezing. Frying time influences greatly the quantity of oil absorbed by the carrot tissue. Caroten oid pigments in frozen carrots are quite stable. Freezing temperature does not affect the level of provitamin $\mathrm{A}$ in the frozen products. There was a slight decrease in provitamin content in the fried product due to the extraction of the carotenoid pigments by the frying oil. Because of the short time of frying at moderate temperature, the retention of the provitamin $\mathrm{A}$ in the product was satisfactory. The fried product has an attractive color, aroma and flavor.

\section{はじめに}

角切りやスライスしたニンジンは小売マーケット用と して小袋詰, あるいは乳幼児食品製造業者用としてコン テナの中で冷凍している (Cruess) ${ }^{11}$ 赤い Chantenay 種 のニンジンは, 良質の色, きめ, 風味を有するため, 冷 凍用として栽培している。 Rahman 2) らはニンジンを冷

*札幌市・宮の森脳神経外科病院

***米国・カリフォニア大学 95616
凍した場合の細胞構造への物理的な影響を調べた。一 $17.8^{\circ} \mathrm{C}$ 凍結では細胞構造に相当な破壊を生じたが, 液体 窒素を使用した $-196^{\circ} \mathrm{C}$ 凍結のニンジンにおける場合, もっとも細胞の損傷は少なかった。そしてなお高い含有 水分とかたいきめを有し，遠心分離により測定した重量 損失と圧力值との間には, ある相関係数が認められたと している。Wolford と Nelson ${ }^{3)}$ は通風冷却, フレオン 12，窒素ガスなどを用いたときの椧凍ニンジンのきめを 比較し, フレオン 12 では 1 分以内に $-17.8^{\circ} \mathrm{C}$ に達するよ 
うに解凍すると，固くパサパサしていたが，窒素ガスで 凍結したものや通風冷却したものは解凍後それほど硬く なかったことを報告している。しかしいずれも冷凍ニン ジンに㧍けるドリップ量, 素揚げにおけるオイル吸收, カロチノイド残量などについては詳しく述べられていな い。本研究はニンジンを $-20^{\circ} \mathrm{C},-196^{\circ} \mathrm{C}$ (窒素ガス)の 2 種類により冷凍してこれらの物理的な変化を調べたも のである。

\section{実験方法}

（1）凍結方法：供試ニンジンは新鮮な Royalchantenay 種 $4.5 \mathrm{~kg}$ を水洗, 選別, はく皮後 $6 \mathrm{~mm}$ 厚さの角切り にし，3 分間 $96^{\circ} \mathrm{C}$ でスチームブランチを行い，次に水 冷, 水切り後, $-20^{\circ} \mathrm{C}$ で12時間，および 6 分間窒素ガス 凍結 $\left(-196{ }^{\circ} \mathrm{C}\right)$ させたニンジンをサラン袋に入れ, $-20^{\circ} \mathrm{C}$ で貯蔵した。

（2）素揚げ：オイル吸収を調べるた为泠凍試料を 0 , 0. 5，1.0の各時間室温で解凍し，揚げ時間を $0,10,20$, $30 ， 40 ， 50,60$ 秒とし, $160 \sim 170^{\circ} \mathrm{C}$ のラダ油中で加熱 した。またカロチノイドとチアミン残量は同様温度のサ ラダ油中で $30,45,60$ 秒の各時間で素揚げした。附着オ イルは紙により除去し, 室温冷却後サラン袋に入れ 1 2 週間一 $20^{\circ} \mathrm{C}$ で貯蔵した後測定した。

(3) 水分：試料の水分は $\mathrm{AOAC}{ }^{4)}$ 代記載されている 真空法に従った。

(4) ドリップ量 : スライスしたニンジンのドリップ量

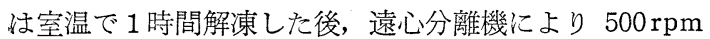
でそれぞれ $1 ， 2 ， 3 ， 4 ， 5$ 分間操作した。抽出液量は中 に小さな金網をいれた小容器を用いて計量し, ニンジン のドリップ量を計算した (Rahman) ${ }^{2)}$ 。

(5) オイル吸収：オイル吸収はソックスレイ抽出法 $(\mathrm{AOAC})^{4}$ により決定した。

(6) カロチノイド: Mgo•Supercil (1:1) コラムを用 い, ヘキサン中のカロチノイド分離のため使用した(AO $(\mathrm{AC})^{4)}$ 。溶剂は $10 \%$ アルコールフリーのア七トンと $90 \%$ のへキサンの混合溶媒（KOH で再蒸留したもの）を用 いた。カロチノイド吸収は $436 \mathrm{~nm}$ で測定し，IU/100 g の単位で表した。

(7) チアミン：チオクローム螢光法 $(\mathrm{AOAC})^{4)}$ を用 いた。

（8）官能試験：解凍ニンジンを $160 \sim 170^{\circ} \mathrm{C}$ のラダ油 中で $0,30,45,60$ 秒間素揚げし，その色，香り，風味
は12人のグループにより1〜10までの評価により決めた $(\mathrm{Luh})^{5)}$

\section{実験結果および考察}

（1） 1 分間隔で遠心分離したのちのドリップ量をFig. 1 亿示す。 $-20^{\circ} \mathrm{C}$ 凍結ニンジンのドリップ量は 4 \%で， $-196{ }^{\circ} \mathrm{C}$ の液体窒素凍結ニンジンのドリップの $1 \%$ に比 し4 倍ほどのドリップ量の差を示した。また液体窒素に よる急速凍結では細胞組織の損傷が比較的少なく $-20^{\circ} \mathrm{C}$

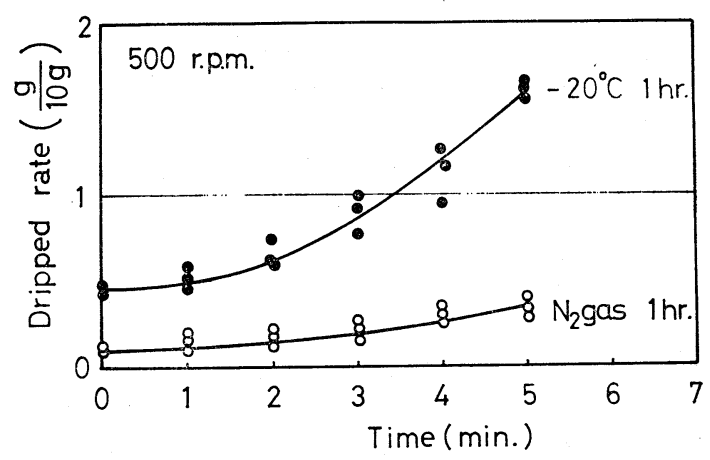

Figure 1. Drip (water loss) in frozen carrot discs after centrifugation of the thawed carrots at $500 \mathrm{rpm}$ for various time intervals,

凍結によるものに比べ良いきめを示した。同様の結果は Wolford と Nelson ${ }^{3)}$ によすでに報告されている。す なわち液体窒素, フレオン12により凍結されたニンジン はかなりかたくパサパサしたきめを持ち，これを解凍し 即席のスナック食品として適当であることを述べてい る。また Rahman ら ${ }^{2)}$ は凍結温度は細胞破壊をひきお こす主要な要素であることを示した。

(2) 素揚げによる変化：素揚げによる重量損失，プロ ビタミンA，チアミン，抢よび $320 \mathrm{~nm}$ 吸収について Table 1 に示した。

a) オイル吸収 : 凍結ニンジンは風味と香りを改善す るため油中で素揚げされる。素揚げはニンジン中の水分 の一部がサラダ油で置換され，風味はオイル吸収により よくなる。室温で $0,0.5,1.0$ の各時間解凍後, 試料は 60 秒までの種々の時間により160 170 Cのサラダ油中で 素揚げされた。 $-20^{\circ} \mathrm{C}$ 凍結と液体窒素による凍結のニン ジンではオイル吸収に差異を生じ, 最大のオイル吸収量 は生重量の $3 \%$ 程度であったが，素揚げ時間の差異によ り吸油量は若干ばらつきがあった（Fig 2)。

b）素揚げによる重量損失：揚げ時間を変えて160〜 $170^{\circ} \mathrm{C}$ のサラダ油中で 素揚げした場合の重量損失に及ぼ 
Table 1. Effect of frying frozen carrot discs in salad oil at $160-170^{\circ} \mathrm{C}$ on carotenoid and thiamin retention

\begin{tabular}{c|c|r|r|r|c}
\hline \hline Sample & $\begin{array}{l}\text { Time of } \\
\text { frxing in } \\
\text { salad oil } \\
\text { at } 160-170^{\circ} \mathrm{C} \\
\text { sec }\end{array}$ & $\begin{array}{l}\text { Weight loss } \\
\text { after frying } \\
\%\end{array}$ & $\begin{array}{l}\text { Provitamin A } \\
\text { value (wet } \\
\text { basis) } \\
\text { IUU/100gm }\end{array}$ & $\begin{array}{l}\text { Thiamin in } \\
\text { fried product } \\
\text { (wet basis) } \\
\text { mg/100gm }\end{array}$ & $\begin{array}{l}\text { Absorption } \\
\text { peak at } \\
324 \mathrm{~nm} \\
\text { (cis-peak) }\end{array}$ \\
\hline 1 & 0 & 0.0 & 13953 & 0.050 & no \\
2 & 30 & 13.0 & 15536 & 0.032 & yes \\
3 & 45 & 19.0 & 18586 & 0.040 & yes \\
4 & 60 & 24.0 & 15886 & 0.040 & yes \\
\hline
\end{tabular}
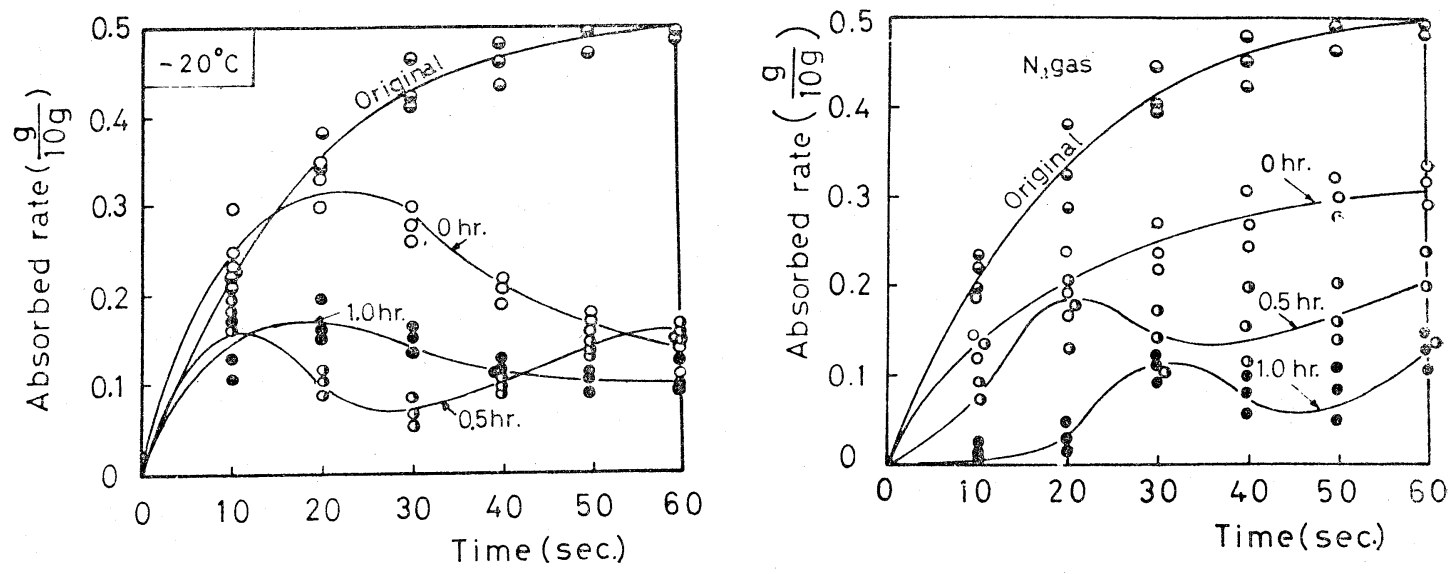

Fig 2. Oil absorbed rate of fried frozen carrot in various time

す影響をみると，素揚げ時間を30秒より60秒にした時の 重量損失は $13 \%$ よ $24 \%$ に増加した。これはサラダ油中 での加熱のためニンジンからの水分蒸発によるためであ った。

c）カロチノイド：揚げ時間 $30 ， 45 ， 60$ 秒の各時間と し160 170C のサラダ油中で素揚げした。素揚げ時間の 増加とともにニンジンの $\beta$-カロチノイドの吸光度は少 しの増加が見られる。この現象は素揚げによりニンジン からの水分が蒸発したためであり, カロチノイド濃度の 増加が説明される。また実際には all-trans $\beta$-カロチン の cis 型への部分的変換があった。これは吸光度測定に より素揚げニンジン中に，324 nm の cis 型のピークが 証明された (Fig 3)。カロチノイドの強烈な色はスペク トル曲線があるかたまった带状を示し，400～500nm 領 域での強い吸光作用により生ずるものである。もし，こ れが振動的微細構造索示すものであるなら, 多くの場合 3 個の最大值または 2 個の最大值と 1 つの肩が最大強度 をもつ中位のピークと共に現われる。all-transカロチイ ドが cis-trans isomer 混合物に変る時, 色の強さは減 少する (zechmeister $)^{6)}$ 。all-trans の cis 型への再編成 の間, スペクトル曲線は変化する。すなわち吸光值と微

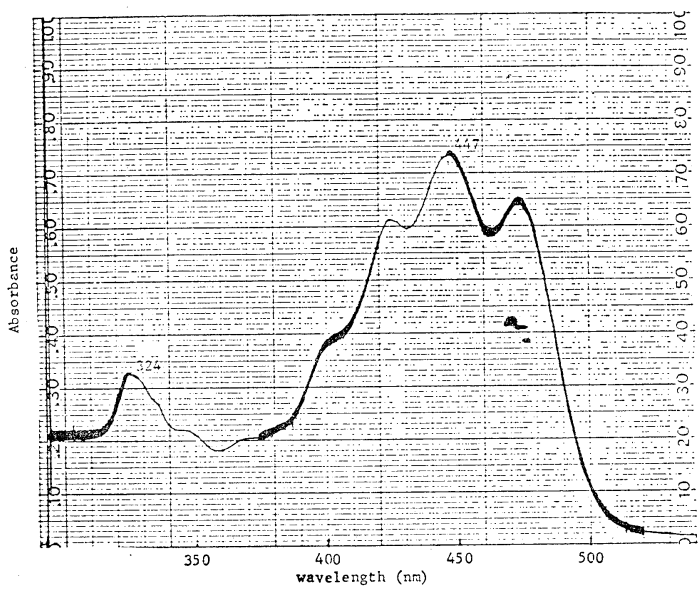

Figure 3. Absorption spectrum of carotenoid from frozen carrots after frying in salad oil at $160-170^{\circ} \mathrm{C}$ for 60 seconds. The cis peak appeared at $324 \mathrm{~nm}$.

細構造の值は減少するが, 一方, 最大值は短波長側一移 行する。

d）チアミン：サラダ油中で解凍ニンジンを素揚げし た時のチアミン残量を Table 1 に示す。解凍ニンジン が $160 \sim 170^{\circ} \mathrm{C}$ のサラダ油中で 30 秒以上素揚げされると 
イド残量に及ぼす凍結方法の影響について

き，チアミンはわずかな減少があった。これは素揚げに よりニンジン組織から細胞液の除去があったためであ る。チアミンは水溶性であり，水分が素揚げにより繊維 より排出される時, チアミンはわずかな減少があった。 これは素揚げによりニンジン組織から細胞液の除去があ ったためである。チアミンは水溶性であり，水分が素揚 げにより繊維より排出される時, 水と共にニンジンを離 れる傾向を持っている。またこの減少に対する説明は高 温によるチアミンの熱的分解である。栄養学的観点から すると素揚げは熱に不安定なビタミンがわずかながら減 少し，望ましくないことと思える。

e）官能試験：素揚げされた解凍ニンジンの官能試験 を Table 2 に示す。素揚げ時間の増加は色彩のわずか な滅少をきたした。しかしコントロールされたものに比 し素揚げしたものは味と香りにより高い評価を得た。 揚げ時間が 30 秒と 45 秒のものが $160-170^{\circ} \mathrm{C}$ の温度で素揚

Table 2. Sensory evaluation of frozen carrot slices fried salad oil at $160-170^{\circ} \mathrm{C}$ for various time intervals

\begin{tabular}{l|rccc}
\hline \hline Sample & $\begin{array}{c}\text { Frying tim } \\
\text { sec. }\end{array}$ & $\begin{array}{c}\text { Average } \\
\text { Color }\end{array}$ & $\begin{array}{c}\text { sensory } \\
\text { Aroma }\end{array}$ & $\begin{array}{c}\text { score* } \\
\text { Flavor }\end{array}$ \\
\hline 1 & 0 & 8.7 & 6.0 & 6.2 \\
2 & 30 & 6.7 & 7.0 & 6.3 \\
3 & 45 & 5.8 & 7.0 & 7.3 \\
4 & 60 & 5.0 & 7.2 & 7.7 \\
L.S.D. & $(\mathrm{p}=.05)$ & 0.9 & 0.8 & 1.0 \\
\hline
\end{tabular}

* scored by a panel of 12 persons on a 1 to 10 scale : excellent, 9-10; good, 7-8; fair, 5-6; poor, 3-4; very poor, $1-2$.

げした場合に官能評価は最も良かった。香りの改善とし ては素揚げはいくつかの揮発性化合物の除去と香りの化 合物が生成されるためであるとされて良い。風味につい ても, ニンジン組織へのサラダ油の吸収はよい結果をも たらしている。

\section{要 約}

Royalchantenay種のニンジンを用いー $196^{\circ} \mathrm{C}$ 液体窒素 の急速凍結と $-20^{\circ} \mathrm{C}$ 緩慢凍結がドリップ量, オイル吸収 量, カロチノイド残量に及ぼす影響を調べた。遠心分離 により測定された解凍時のドリップ量は緩慢凍 結で 4 \%，液体窒素凍結で $1 \%$ であった。この 2 つの方法によ
るドリップ量の差異は緩慢凍結による細胞構造の変化の ためであろう。緩慢凍結は氷晶生成の間，繊維のひきさ きつぶれなどのため泠凍ニンジンの繊維構造やきめに 損傷を与える。冷凍ニンジンのスライスを 1 時間室温で 解凍したのち，160 $170^{\circ} \mathrm{C}$ のラダ油で 30 秒から60秒間 素揚げされたとき，ニンジン組織に吸収されたオイルは $3 \%$ に達する。素揚げ時間はニンジン組織への油の吸収 に対し非常に影響している。all-trans $\beta$-カロチンの cis 型への部分的な変換は，油で素揚げするために起こ ると考えてよい。このことは素揚げ後に $324 \mathrm{~nm}$ の吸収 ピークが現れることによって明らかである。ニンジンの チアミン量は素揚げにより細胞液の損失と熱的分解のた めわずかながら減少した。官能試験は解凍ニンジンの揚 げ時間を 30 秒から 45 秒とし，160 170 ${ }^{\circ} \mathrm{C}$ の温度で素揚げ することにより最もよい評洒が得られた。

\section{REFERENCES}

1) Cruess, W. V. 1958. Commercial Fruit and Vegetale Products, 4 th ed. McGraw Hill Book Co., New York, N. Y.

2) Rahman, A. R., Henning, W. L., and Westcott, D. E. 1971. Histological and Physical changes in carrots as affected by blanching, cooking, freeze-drying, and compression. J. Food Sci. $36,500$.

3) Wolford, E. R., and Nelson, J. W. 1971. Comparison of texture of carrots frozen by airblast, food freezant-12 and nitrogen vapor. J. Food Sci. 36, 959-961.

4) AOAC. 1970 Official Methods of Analysis, 11th ed. Assoc. Offic. Anal. Chemists, Washington, D. C.

5 ) Luh, B. S., Antonakos, J., and Daoud, H. N. 1969. Chemical and quality changes in strained carrots canned by the aseptic and retort processes. Food Technol. 23(3), 103-107.

6) Zechmeister, L. 1962. Cis-Trans Isomeric Carotenoids, Vitamin A and Arylpolyenes. Academic Press Inc., New York, N. Y. 